\title{
The Effectiveness of Hearing Protection Devices: A Systematic Review and Meta-Analysis
}

\author{
Chanbeom Kwak ${ }^{1,2}$ (D) and Woojae Han ${ }^{1,2, *(D)}$ \\ 1 Laboratory of Hearing and Technology, Research Institute of Audiology and Speech Pathology, College of \\ Natural Sciences, Hallym University, Chuncheon 24252, Korea; cksqja654@gmail.com \\ 2 Division of Speech Pathology and Audiology, College of Natural Sciences, Hallym University, \\ Chuncheon 24252, Korea \\ * Correspondence: woojaehan@hallym.ac.kr; Tel.: +82-33-248-2216
}

Citation: Kwak, C.; Han, W. The Effectiveness of Hearing Protection Devices: A Systematic Review and Meta-Analysis. Int. J. Environ. Res. Public Health 2021, 18, 11693. https:// doi.org/10.3390/ijerph182111693

Academic Editor: Ivo Iavicoli

Received: 13 October 2021

Accepted: 5 November 2021

Published: 7 November 2021

Publisher's Note: MDPI stays neutral with regard to jurisdictional claims in published maps and institutional affiliations.

Copyright: (c) 2021 by the authors. Licensee MDPI, Basel, Switzerland. This article is an open access article distributed under the terms and conditions of the Creative Commons Attribution (CC BY) license (https:// creativecommons.org/licenses/by/ $4.0 /)$.

\begin{abstract}
To prevent intensive noise exposure in advance and be safely controlled during such exposure, hearing protection devices (HPDs) have been widely used by workers. The present study evaluates the effectiveness of these HPDs, partitioned into three different outcomes, such as sound attenuation, sound localization, and speech perception. Seven electronic journal databases were used to search for published articles from 2000 to 2021. Based on inclusion criteria, 20 articles were chosen and then analyzed. For a systematic review and meta-analysis, standardized mean differences (SMDs) and effect size were calculated using a random-effect model. The funnel plot and Egger's regression analysis were conducted to assess the risk of bias. From the overall results of the included 20 articles, we found that the HPD function performed significantly well for their users (SMDs: 0.457, 95\% confidence interval $(\mathrm{CI}): 0.034-0.881, p<0.05)$. Specifically, a subgroup analysis showed a meaningful difference in sound attenuation (SMDs: $1.080,95 \%$ CI: 0.167-1.993, $p<0.05$ ) when to wear and not to wear HPDs, but indicated no significance between the groups for sound localization (SMDs: 0.177, 95\% CI: $0.540-0.894, p=0.628$ ) and speech perception (SMDs: $0.366,95 \%$ CI: $-0.100-1.086, p=0.103$ ). The HPDs work well for their originally designated purposes without interfering to find the location of the sound sources and for talking between the workers. Taking into account various factors, such as the characteristics of the users, selection of appropriate types, and fitting methods for wearing in different circumstances, seems to be necessary for a reliable systematic analysis in terms of offering the most useful information to the workers.
\end{abstract}

Keywords: noise-induced hearing loss; hearing protection; sound attenuation; sound localization; communication

\section{Introduction}

It is clearly acknowledged that industrial workers and individuals in military service have inevitably faced more noise exposure and that exposure has increased the incidence of noise-induced hearing loss (NIHL) [1,2]. Not only temporary noise exposure of high intensity (i.e., more than $85 \mathrm{dBA}$ ) in terms of level of intensity, but also continuous exposure to moderate-intensity noise in terms of frequency can contribute seriously to negative effects on the human auditory system [1,2]. Thus, noise is regarded as a decisive factor producing the hearing loss of workers [3] and consequently accompanying other otologic problems and diseases such as tinnitus, poor hearing ability for situational awareness and communication, and psychological problems such as a lower quality of life [4].

To prevent such exposure to intensive noise in advance and be safely controlled during exposure, hearing protection devices (HPDs) have been under development for several decades. Although HPDs seem to be a passive method of noise control, they are the most practical and good enough when appropriately fitted for a correct size and have received adequate maintenance [5,6]. Unlike their original purpose, however, many workers are frequently reluctant or even do not wear these devices due to discomfort and a tight 
fit feeling even in a noisy environment [4]. Further, the sound attenuation obtained by wearing the HPDs, which is a key function to prevent NIHL [7], may decrease the ability to identify sound localization [8-10] and achieve speech perception $[3,11-13]$. Therefore, many researchers have studied the functions and effects of HPDs whenever a new device is released. Regardless, these studies have produced a problem, namely, how to organize and summarize their different findings, consequently resulting in the suggestion of needing a systematic analysis to achieve the highest level of evidence. Hence, we aimed to evaluate the major functions of the HPDs using systematic review and meta-analysis techniques. More specifically, the effectiveness of HPDs was partitioned to three different functions and effects, including sound attenuation, sound localization, and speech perception, which can give the users clearer expectations about the efficiency of these HPDs when wearing them.

\section{Materials and Methods}

\subsection{Strategy for Systematic Search}

The Preferred Reporting Items for Systematic Reviews and Meta-analysis (PRISMA) 2020 statement [14] and the International Prospective Register of Systematic Reviews (PROSPERO) of Cochrane Collaboration [15] were used as a methodology that commonly processes the systematic search for and meta-analysis of published articles and their review was reported. The PROSPERO registration number was CRD42021276424.

The process applied for the inclusion criteria of articles for the systematic review and meta-analysis $[14,15]$ combined a strategy using participants, intervention, control, outcome measures, and study design (PICOS). Table 1 displays the PICOS criteria used in the present study. On the other hand, our exclusion criteria were modeling studies, engineering design, no research article (e.g., narrative review paper, conference abstract, letters, book and book chapters, magazines, and proceeding paper), and not being written in English.

Table 1. Inclusion criteria for the present study using Participants, Intervention, Control, Outcomes, and Study Designs (PICOS) Strategy.

\begin{tabular}{ll}
\hline Parameter & Inclusion Criteria \\
\hline Participants & Adults 18 years or older with and without hearing loss \\
\hline Intervention & $\begin{array}{l}\text { Functions and effects of hearing protection devices (i.e., comparison of wearing or not wearing hearing } \\
\text { protection devices or a comparison of the types of hearing protection devices) }\end{array}$ \\
\hline Control & Comparison to control group or repeated measures (experiments with additional purposes) \\
\hline Outcomes & $\begin{array}{l}\text { Outcome measure(s) related to functions and/or effects of hearing protection devices (i.e., sound } \\
\text { attenuation, sound localization, and speech perception) }\end{array}$ \\
\hline Study Designs & $\begin{array}{l}\text { Randomized controlled trials, non-randomized controlled trials, and repeated measures (experiments with } \\
\text { additional purposes) }\end{array}$ \\
\hline
\end{tabular}

\subsection{Article Selection}

Seven electronic databases (i.e., Embase, Medline, Pubmed, Web of Science, Science Direct, Scopus, Cumulative Index to Nursing and Allied Health) were used and searched from January 2000 to June 2021 using the key terms, "hearing protection devices" OR "hearing protector" AND "hearing protection devices effects" OR "effects" OR "attenuation" OR "intervention" OR "sound localization" OR "benefits" OR "speech intelligibility". The terms were always combined to limit identifying duplicate papers.

Initially, the number of articles searched in the electronic databases equaled 3971. After eliminating 2118 articles which were met the exclusion criteria due to duplication, 1853 articles remained. As a part of the screening process, their titles and abstracts were confirmed to exclude 1166 records. Then, only 687 articles were accessed to review their full texts at the eligibility stage. Further, because 667 studies failed to meet the PICOS 
criteria for several reasons (i.e., participants in industrial work and irrelevant outcome measures), a total of 20 articles were included for the specific review. Figure 1 explains each of these steps visually.

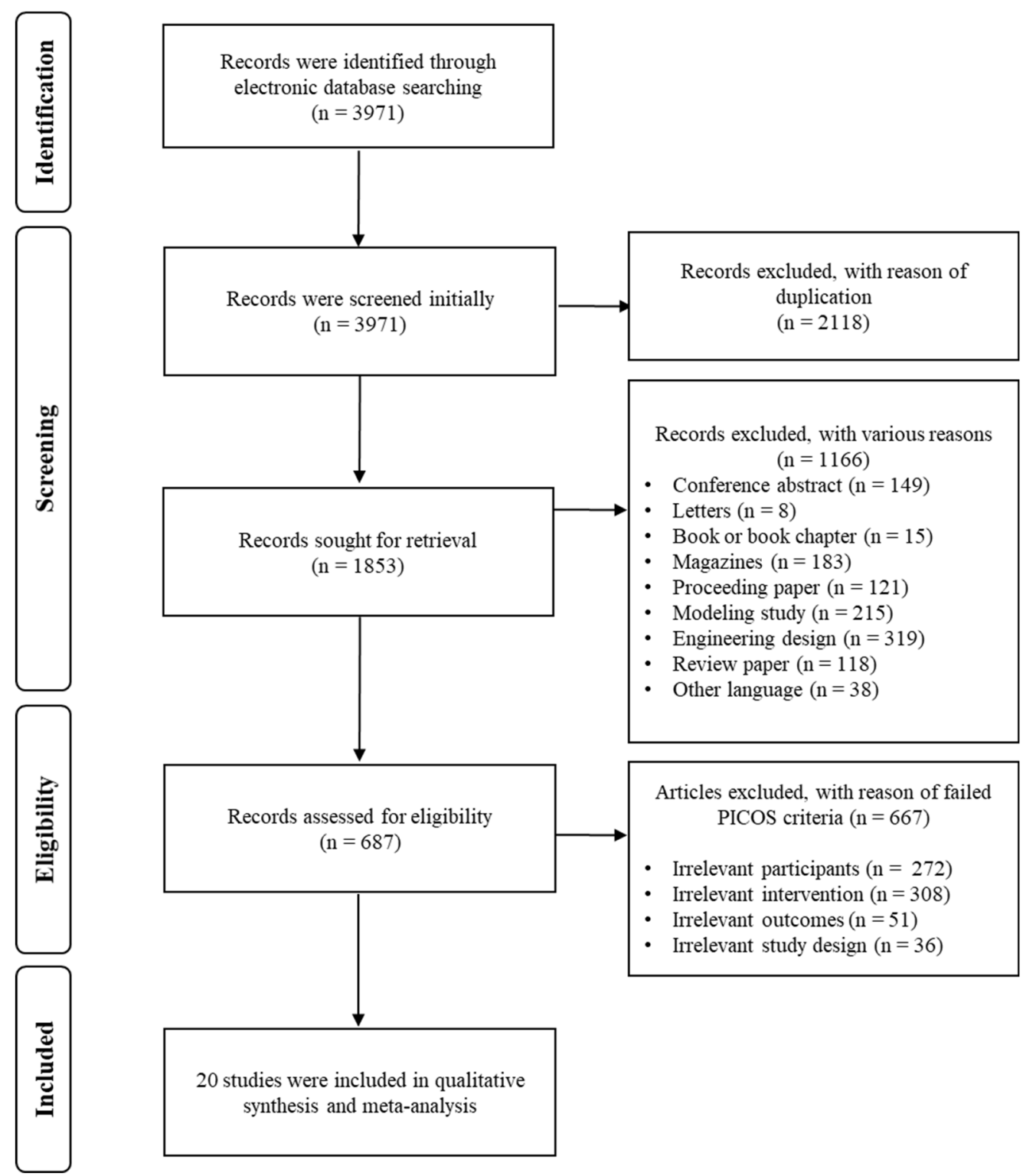

Figure 1. A Preferred Reporting for Items for a Systematic Review and Meta-analysis (PRISMA) flow diagram to explain the inclusion and exclusion process of the current study.

\subsection{Study Quality and Potential Sources of Study Bias}

To evaluate both study quality and potential sources of any study bias, the CAMARADES checklist was used [16]. It contained six independent items, namely, randomization (pseudo-randomization of participants allocation, test condition, or materials), controls, sample size calculation (calculation of the appropriate number of study sample produced using power analysis), articles published with peer review, outcome measure, and statement of potential conflict of interests (see Table 2 for details). The scores were calculated using 1, which was assigned by the item (i.e., YES), or 0 (i.e., NO). After providing scores for study quality, each study was summed up at the level of the evidence based on the Grading of Recommendations, Assessment, Development, and Evaluation (GRADE) Working Group Guideline [17]. The study quality scores of selected articles were analyzed by 
the chi-square test. Simply put, as the level of evidence increased, the results of the study were considered to be valid.

Table 2. Analysis of the scientific study validity criteria based on CAMARADES checklists [16].

\begin{tabular}{|c|c|c|c|c|c|c|c|}
\hline \multirow[b]{2}{*}{ Study } & \multicolumn{6}{|c|}{ Scientific Study Validity Criteria } & \multirow{2}{*}{$\begin{array}{c}\text { Study } \\
\text { Quality } \\
\text { Score }\end{array}$} \\
\hline & Randomization & Controls & $\begin{array}{l}\text { Sample Size } \\
\text { Calculation }\end{array}$ & $\begin{array}{l}\text { Publication after } \\
\text { Peer Review }\end{array}$ & $\begin{array}{l}\text { Outcome } \\
\text { Measure }\end{array}$ & $\begin{array}{l}\text { Statement of Potential } \\
\text { Conflict of Interest }\end{array}$ & \\
\hline Smalt et al. (2019) [3] & 1 & 0 & 0 & 1 & 1 & 1 & 4 \\
\hline Brown et al. (2015) [4] & 1 & 0 & 0 & 1 & 1 & 1 & 4 \\
\hline Abel et al. (2002) [5] & 1 & 1 & 0 & 1 & 1 & 0 & 4 \\
\hline Tufts et al. (2012) [7] & 0 & 0 & 0 & 1 & 1 & 0 & 2 \\
\hline Abel and Paik (2005) [8] & 1 & 0 & 0 & 1 & 1 & 1 & 4 \\
\hline Carmichel et al. (2007) [9] & 1 & 0 & 0 & 1 & 1 & 1 & 4 \\
\hline Talcott et al. (2012) [10] & 1 & 0 & 0 & 1 & 1 & 1 & 4 \\
\hline Byrne and Palmer (2012) [11] & 0 & 0 & 0 & 1 & 1 & 1 & 3 \\
\hline Dastpaak et al. (2019) [12] & 1 & 0 & 0 & 1 & 1 & 1 & 4 \\
\hline Tufts and Frank (2003) [13] & 1 & 0 & 0 & 1 & 1 & 0 & 3 \\
\hline Alali and Casali (2011) [18] & 1 & 0 & 0 & 1 & 1 & 1 & 4 \\
\hline Plyler and Klumpp (2003) [19] & 1 & 0 & 0 & 1 & 1 & 0 & 3 \\
\hline Abel and Lam (2004) [20] & 0 & 0 & 0 & 1 & 1 & 0 & 2 \\
\hline Casali et al. (2004) [21] & 1 & 0 & 0 & 1 & 1 & 0 & 3 \\
\hline de Faria and Suzuki (2008) [22] & 0 & 0 & 0 & 1 & 1 & 0 & 2 \\
\hline Bolia et al. (2001) [23] & 1 & 0 & 0 & 1 & 1 & 0 & 3 \\
\hline Simpson et al. (2005) [24] & 1 & 0 & 0 & 1 & 1 & 0 & 3 \\
\hline Zimpfer and Sarafian (2014) [25] & 1 & 0 & 0 & 1 & 1 & 1 & 4 \\
\hline Giguère et al. (2015) [26] & 1 & 1 & 0 & 1 & 1 & 1 & 5 \\
\hline Manning et al. (2016) [27] & 1 & 1 & 0 & 1 & 1 & 0 & 4 \\
\hline
\end{tabular}

The data contained in the articles were extracted and synthesized for the following content: (1) participants (number, age, sex, and hearing threshold); (2) types of hearing protection devices; (3) study design; (4) the main factor of the experiments (i.e., level of attenuation, ability of sound localization, and performance of speech perception); (5) outcome measures; and (6) major findings. Two authors (C.K. and W.H.) conducted the process independently and then any discrepancies (less than $5 \%$ ) were resolved by consensus between the two authors.

\subsection{Meta-Analysis}

The included articles were identified to determine whether their data were suitable for meta-analysis. Comprehensive Meta-Analysis software (Ver. 3, Biostat Inc., Englewood, NJ, USA) was used to conduct the meta-analysis. The data collected from the included articles were continuous, and the same outcome measures, mean differences (MDs), were calculated with 95\% confidence intervals (CIs). However, when the data having different outcome measures were collected, the effect sizes were calculated using standardized mean differences (SMDs). After the effect sizes were calculated, a summary estimate was examined. As the participants in the reviewed articles were adults, both with and without hearing loss, the random-effect model was used to calculate the effect size and summary estimate. Heterogeneity (genuine differences underlying the results of the studies) [28] across the articles was identified using the Higgins $I^{2}$-statistics and Cochran's Q-test. To quantify heterogeneity, Higgins $I^{2}$ provided a value from 0 to $100 \%$ : $0-25 \%$ for low, $25-75 \%$ for moderate, and $75-100 \%$ for high [28]. Cochran's Q-test indicated a $95 \%$ statistical significance level $(p<0.05)$. The subgroup analysis, which categorized the articles as having three remarkable features (e.g., sound attenuation, sound localization, and speech perception) and meta-regression were considered due to the possibility of high heterogeneity and/or different outcome measures for the reviewed studies.

Reporting bias occurred when the reporting and spreading of the results of studies were influenced by their characteristics and directions of their main findings. The most representative was a publication bias where the studies having statistically significant differences had a larger possibility of publication compared to those studies with no significant differences. Since the publication bias usually produced distorted results for the meta-analysis [29], the funnel plot and Egger's regression test were used to identify it. The 
funnel plot is a kind of scatter plot consisting of a y-axis for the sample size of studies and an $\mathrm{x}$-axis for the effect size.

\section{Results}

\subsection{Study Quality Scores}

The scores for study quality, based on the CAMARADES checklists, were analyzed using a chi-square test and $R$ statistical computing software [30]. The mean value of the study quality scores was 3.45 (SD: 0.83 , range: $2 \sim 5$ ). Then, to identify the goodness of fit for the study quality scores, a chi-square test was also conducted using the R software [30]. There were no significant differences between the study quality scores $\left(x^{2}=3.7536, \mathrm{df}=19\right.$, $p>0.05)$.

\subsection{Charactersits of Studies \\ 3.2.1. Participants}

The summarized results of the reviewed studies according to the PICOS criteria are displayed in Table 3. The participants included individuals with both normal hearing $[4,7-13,18-25]$ and hearing loss $[3,5,26]$. Specifically, Smalt et al. reported on one single individual with a threshold of $30 \mathrm{~dB}$ HL in one ear [3] and Abel et al. had 24 older adults with hearing loss [5]. In the study of Giguère and colleagues, the subjects were divided into four groups, e.g., normal hearing, slight-to-mild hearing loss, mild-to-moderate hearing loss, and moderate-to-severe hearing loss [26].

\subsubsection{Intervention}

Types of HPDs, their functions and effects were evaluated as the intervention. Six of twenty studies conducted a comparison between types of HPDs. For example, in the study by Simpson et al., types of HPDs for earplugs, earmuffs, and a combination of earplugs and earmuffs [24] were compared. On the other hand, fourteen of twenty studies compared two conditions for when to wear and not to wear HPDs by using various scenarios of use, such as earplugs only $[3,7,10,12,13,19,20,22]$, earmuffs only $[5,8,9,11]$, earplugs and/or earmuffs $[4,18,21,23,25,26]$, earplugs with earmuffs [24], and headsets [27]. In terms of functions and effects, only six of twenty studies used passive noise reduction HPDs such as earplugs and earmuffs $[5,7,13,20,23,24]$. More than half of the studies (fourteen of twenty studies) used HPDs with a function for active noise reduction [3,4,8-12,18,19,21,22,25-27].

\subsubsection{Controls and Study Designs}

It was desirable to ensure that there was high-level evidence (i.e., randomized controlled trials) for the research articles [31]. Additionally, a between-group comparison (i.e., experimental group versus control group) was regarded as an alternative choice to use to confirm the effects of the experiment. In the current review, only three of twenty studies used between-group comparisons $[5,8,26]$, and the other seventeen studies were conducted using repeated measures under various conditions [3,4,7,9-13,18-20,22-25]. In the other view, although three of the twenty studies provided between-group comparisons [5,8,26], twenty studies, including the aforementioned three, were used repeated measures that compared types of HPDs or made comparisons with and without HPDs.

\subsubsection{Outcomes}

To identify the functions and effects of HPDs, the outcomes of the reviewed studies were classified. Five of twenty studies mainly determined the functions and effects of HPDs by sound attenuation $[5,7,20-22]$. Outcomes of sound localization and speech perception were reported by eight $[4,8-10,18,23-25]$ and seven $[3,11-13,19,26,27]$ of the twenty studies, respectively. 
Table 3. Characteristics and effects of hearing protection devices for all enrolled studies for the participants, intervention, control group, and outcome of each study.

\begin{tabular}{|c|c|c|c|c|c|c|c|}
\hline Study & Participants & Test Materials and Conditions & $\begin{array}{c}\text { Study } \\
\text { Design }\end{array}$ & $\begin{array}{l}\text { Major } \\
\text { Function }\end{array}$ & $\begin{array}{l}\text { Outcome } \\
\text { Measures }\end{array}$ & Main Findings & Effects of HPD \\
\hline $\begin{array}{l}\text { Abel } \\
\text { et al. } \\
(2002) \\
{[5]}\end{array}$ & $\begin{array}{l}\text { Twenty-four } \\
\text { young adults with } \\
\text { normal hearing } \\
\text { (aged under } \\
40 \text { years), } \\
\text { twenty-four older } \\
\text { adults with } \\
\text { normal hearing } \\
\text { (aged } \\
\text { over } 40 \text { years), } \\
\text { and twenty-four } \\
\text { older adults with } \\
\text { hearing loss }\end{array}$ & $\begin{array}{l}\text { A total of five ear conditions } \\
\text { were adjusted: (1) ears under } \\
\text { unoccluded conditions, (2) ears } \\
\text { with Class A muffs, (3) ears with } \\
\text { muffs on hard hat and } \\
\text { air-purifying half-mask } \\
\text { respirators, (4) ears with muffs } \\
\text { on hard hat and safety glasses, } \\
\text { and (5) ears with muffs on hard } \\
\text { hat, safety glasses, and } \\
\text { respirators. Attenuation } \\
\text { measurements were conducted } \\
\text { for eight one-third octave noise } \\
\text { bands centered from } 0.25 \text { to } \\
8 \mathrm{kHz} \text {. }\end{array}$ & $\begin{array}{l}\text { Repeated } \\
\text { measures }\end{array}$ & Attenuation & $\begin{array}{l}\text { Amount of } \\
\text { attenuation } \\
\text { (dB SPL) }\end{array}$ & $\begin{array}{l}\text { The results of ANOVA } \\
\text { with repeated } \\
\text { measures showed } \\
\text { significant effects for } \\
\text { group }[\mathrm{F}(5,61)=4.3, \\
p<0.002], \text { protector } \\
\text { condition } \\
{[\mathrm{F}(3,183)=104.2,} \\
p<0.0001], \text { and } \\
\text { frequency } \\
{[\mathrm{F}(7,427)=387.7,} \\
p<0.0001] . \text { The } \\
\text { interaction of the } \\
\text { protector condition by } \\
\text { group }[\mathrm{F}(35,427)=1.8, \\
p<0.006], \text { protector } \\
\text { condition by group } \\
{[\mathrm{F}(21,1281)=12.2,} \\
p<0.0001], \text { protector } \\
\text { condition by frequency } \\
\text { by group } \\
{[\mathrm{F}(105,1281)=6.8,} \\
p<0.04] \text {. The } \\
\text { interaction with } \\
\text { protector condition by } \\
\text { group was not } \\
\text { significant. }\end{array}$ & $\begin{array}{l}\text { Averaged across } \\
\text { protector conditions, } \\
\text { attenuation showed } \\
\text { significant increases at } \\
\text { frequency increased from } \\
0.25 \text { to } 1 \mathrm{kHz} \text { and then } \\
\text { remained constant, } \\
\text { except for a dip at } \\
6.3 \mathrm{kHz} \text {. Averaged across } \\
\text { groups and frequencies, } \\
\text { the least attenuation was } \\
\text { achieved with the muff } \\
\text { on hard hat in } \\
\text { combination with the } \\
\text { glasses and respirator. } \\
\text { The muff on hard hat } \\
\text { alone condition showed } \\
\text { highest attenuation. The } \\
\text { range in attenuation in } \\
\text { order to the conditions } \\
\text { was greater at } 0.25 \text { and } \\
0.5 \mathrm{kHz}(9 \mathrm{~dB} \text { ) and at its } \\
\text { lowest } 2 \text { and } 3.15 \mathrm{kHz} \\
(3-4 \mathrm{~dB}) \text {. }\end{array}$ \\
\hline $\begin{array}{l}\text { Abel } \\
\text { and } \\
\text { Lam } \\
(2004) \\
{[20]}\end{array}$ & $\begin{array}{l}\text { Sixteen adults } \\
\text { ages from } 21 \text { to } \\
53 \text { years }(8 \text { men } \\
\text { and } 8 \text { women) } \\
\text { with normal } \\
\text { hearing }\end{array}$ & $\begin{array}{l}\text { The Indoor and Outdoor E-A-R } \\
\text { plugs manufactured by the Aero } \\
\text { Company were used. The } \\
\text { hearing thresholds were } \\
\text { measured on nine } \\
\text { one-third-octave noise bands } \\
\text { (i.e., } 0.125,0,25,0,5,1,2,3.15,4, \\
6.3, \text { and } 8 \mathrm{kHz} \text { for three } \\
\text { conditions (i.e., unoccluded, } \\
\text { indoor plug, and outdoor plug) }\end{array}$ & $\begin{array}{l}\text { Repeated } \\
\text { measures }\end{array}$ & Attenuation & $\begin{array}{l}\text { Amount of } \\
\text { attenuation } \\
\text { (dB). }\end{array}$ & $\begin{array}{l}\text { The results of ANOVA } \\
\text { with repeated } \\
\text { measures showed } \\
\text { significant effects of } \\
\text { ear condition, } \\
\text { frequency and ear by } \\
\text { frequency } \\
\text { ( } p<0.0001) \text {. Post hoc } \\
\text { comparison showed } \\
\text { that the differences in } \\
\text { attenuation for the two } \\
\text { devices was significant } \\
\text { for all testing } \\
\text { frequencies ( } p<0.001 \\
\text { or better). }\end{array}$ & $\begin{array}{l}\text { The attenuation values in } \\
\text { the indoor plug increased } \\
\text { from } 21 \mathrm{~dB} \text { at } 0.125 \mathrm{kHz} \\
\text { to } 40 \mathrm{~dB} \text { at } 8 \mathrm{kHz} \text {. } \\
\text { Additionally, the results } \\
\text { for the outdoor plug } \\
\text { attenuated the thresholds } \\
\text { by } 5 \text { and } 14 \mathrm{~dB} \text { at } 0.5 \mathrm{kHz} \\
\text { and } 1 \mathrm{kHz} \text {. }\end{array}$ \\
\hline
\end{tabular}

\begin{tabular}{|c|c|c|c|c|c|}
\hline $\begin{array}{l}\text { Abel } \\
\text { and } \\
\text { Paik } \\
(2005) \\
{[8]}\end{array}$ & $\begin{array}{l}\text { Twelve young } \\
\text { adults (age } \\
\text { range-18 to } \\
30 \text { years) and } \\
\text { twelve older } \\
\text { adults (age } \\
\text { range-40 to } \\
55 \text { years) with } \\
\text { normal hearing }\end{array}$ & $\begin{array}{l}\text { Three ear conditions (i.e., with } \\
\text { and without ANR earmuff } \\
\text { operational and unoccluded ear) } \\
\text { were used. A total of eight } \\
\text { speakers formed eight azimuth } \\
\text { angles (i.e., } 15,75,105,165,195 \text {, } \\
255,285 \text {, and } 345 \text { degrees). For } \\
\text { the sound source identification } \\
\text { task, three different signals, such } \\
\text { as } 0.5 \mathrm{kHz}, 4 \mathrm{kHz} \text {, and } \\
\text { broadband noise, were } \\
\text { presented. }\end{array}$ & $\begin{array}{l}\text { Repeated } \\
\text { measures }\end{array}$ & $\begin{array}{l}\text { Sound lo- } \\
\text { calization }\end{array}$ & $\begin{array}{l}\text { Response } \\
\text { time (ms) for } \\
\text { sound source } \\
\text { identification }\end{array}$ \\
\hline
\end{tabular}

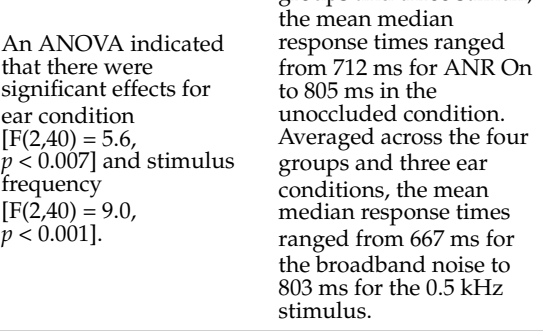

The ANOVA revealed the significant main effects of HPD for a
percentage correct percentage correct
localization localization
$[\mathrm{F}(7,77)=59.2$ $p<0.0001]$, percentage of right-left localization errors $[\mathrm{F}(7,77)=42.78$, $p<0.0001]$, percentage 2 signals $\times 2$ presentation levels) were adjusted. The HPDs consisted of: (1) unoccluded, (2) foam earplug, (3) pre-molded

$\begin{array}{ll}\text { Alali } & \text { Twelve adults } \\ \text { and } & \begin{array}{l}\text { (older than } \\ \text { Casali }\end{array} \\ \text { (2011) } & \text { normal hearing } \\ \text { [18] } & \text { normal hearing }\end{array}$
earplug, (4) flat attenuation HPD, (5) level-dependent HPD, (6) passive earmuff, (7) dichotic sound transmission earmuff, and
(8) custom-made diotic sound transmission earmuff. The signals consisted of a standard backup alarm and spectrally modified one. Presentation levels of pink noise were both $60 \mathrm{dBA}$ and $90 \mathrm{dBA}$.

$\begin{array}{lll}\begin{array}{l}\text { Repeated } \\ \text { measures }\end{array} & \begin{array}{l}\text { Sound lo- } \\ \text { calization }\end{array} & \begin{array}{l}\text { Percentage } \\ \text { correct }(\%) \text { of } \\ \text { sound } \\ \text { identification. }\end{array}\end{array}$
$p<0.0001]$. The of front-rear

$[\mathrm{F}(7,77)=43.03$

$[\mathrm{F}(7,77)=43.03$
$p<0.0001]$

$p<0.0001]$, and
localization absolute deviation in degrees $[\mathrm{F}(7,77)=92.67$, HPD and background noise level on noise level on
percentage correct localization response localization response
was also significant $[\mathrm{F}(7,77)=9.51$,
$p<0.0001]$.
The mean values of percentage correctness localization showed that flat attenuation HPD $(83.9 \%)$ was the most correct in terms of percentage. Unoccluded $(82.2 \%)$, pre-molded earplug $(81.5 \%)$, and passive earmuff followed, but were not significant. The custom-made diotic sound transmission earmuff $(66.3 \%)$ and foam earplug $(64.6 \%)$ showed similar percentages of correctness. The dichotic sound transmission earmuff $(15.8 \%)$ showed the lowest percentage correctness for localization. 
Table 3. Cont.

\begin{tabular}{|c|c|c|c|c|c|c|c|}
\hline Study & Participants & Test Materials and Conditions & $\begin{array}{c}\text { Study } \\
\text { Design }\end{array}$ & $\begin{array}{l}\text { Major } \\
\text { Function }\end{array}$ & $\begin{array}{l}\text { Outcome } \\
\text { Measures }\end{array}$ & Main Findings & Effects of HPD \\
\hline $\begin{array}{l}\text { Bolia } \\
\text { et al. } \\
2001 \\
{[23]}\end{array}$ & $\begin{array}{l}\text { Six adults (aged } \\
18 \text { to } 34 \text { years) } \\
\text { with normal } \\
\text { hearing }\end{array}$ & $\begin{array}{l}\text { Three hearing protector } \\
\text { conditions (i.e., earplugs, } \\
\text { earmuffs, and unoccluded ear) } \\
\text { were adjusted factorially with } \\
\text { three source elevation conditions } \\
\text { (upper hemisphere, } \\
\text { peri-horizontal region, and lower } \\
\text { hemisphere) for a total of nine } \\
\text { experimental conditions. }\end{array}$ & $\begin{array}{l}\text { Repeated } \\
\text { measures }\end{array}$ & $\begin{array}{l}\text { Sound lo- } \\
\text { calization }\end{array}$ & $\begin{array}{l}\text { Azimuth } \\
\text { error }\left({ }^{\circ}\right)\end{array}$ & $\begin{array}{l}\text { Mean azimuth errors } \\
\text { were analyzed using a } \\
3 \text { (hearing protector) } \times \\
3 \text { (source elevation) } \\
\text { repeated-measures } \\
\text { ANOVA, employing } \\
\text { the Huynh-Feldt } \\
\text { correction, which } \\
\text { revealed significant } \\
\text { main effects of hearing } \\
\text { protector, } \\
{[\mathrm{F}(2,10)=29.94,} \\
p<0.05], \text { and source } \\
\text { elevation, } \\
{[\mathrm{F}(2,10)=19.96,} \\
p<0.05], \text { and a } \\
\text { Hearing Protector } \times \\
\text { Source Elevation } \\
\text { interaction, } \\
{[\mathrm{F}(4,20)=10.86,} \\
p<0.05] \text {. }\end{array}$ & $\begin{array}{l}\text { All simple main effects of } \\
\text { the hearing protector } \\
\text { factor were statistically } \\
\text { significant }(p<0.01) \text {, } \\
\text { implying that at one or } \\
\text { more levels of the source } \\
\text { elevation factor, } \\
\text { performance varies as a } \\
\text { function of the HPD } \\
\text { factor. }\end{array}$ \\
\hline $\begin{array}{l}\text { Brown } \\
\text { et al. } \\
\text { (2015) } \\
{[4]}\end{array}$ & $\begin{array}{l}\text { Ten normal } \\
\text { hearing adults } \\
\text { (mean age: } \\
29.5 \text { years) }\end{array}$ & $\begin{array}{l}\text { Four HPDs and one control } \\
\text { (unoccluded) were used in the } \\
\text { experiment: (1) passive HPD, (2) } \\
\text { active HPD, (3) hybrid HPD, and } \\
\text { (4) ShotShields HPD. }\end{array}$ & $\begin{array}{l}\text { Repeated } \\
\text { measures }\end{array}$ & $\begin{array}{l}\text { Sound lo- } \\
\text { calization }\end{array}$ & $\begin{array}{l}\text { Response } \\
\text { angle }\left(^{\circ}\right)\end{array}$ & $\begin{array}{l}\text { The ANOVA indicated } \\
\text { a significant main } \\
\text { effect of device } \\
\text { condition } \\
{[\mathrm{F}(4,36)=13.64 \text {, }} \\
p<0.001] \text { and target } \\
\text { angle }[\mathrm{F}(11,99)=5.67, \\
p<0.001] \text {. A significant } \\
\text { interaction between } \\
\text { the device and target } \\
\text { angle }[\mathrm{F}(44,396)=5.67, \\
p<0.001] \text { was } \\
\text { revealed. }\end{array}$ & $\begin{array}{l}\text { All tested HPDs } \\
\text { significantly degraded } \\
\text { localization performance } \\
\text { relative to control } \\
\text { (unoccluded) condition. } \\
\text { However, post hoc } \\
\text { analysis of HPD-related } \\
\text { distortions of sound } \\
\text { source localization cues } \\
\text { demonstrated that the } \\
\text { ShotShields produced } \\
\text { both the best behavioral } \\
\text { performance and the } \\
\text { greatest preservation of } \\
\text { sound source cues. }\end{array}$ \\
\hline $\begin{array}{l}\text { Byrne } \\
\text { and } \\
\text { Palmer } \\
\text { (2012) } \\
{[11]}\end{array}$ & $\begin{array}{l}\text { Fifteen adults } \\
\text { with normal } \\
\text { hearing (age } \\
\text { range-21 to } \\
60 \text { years) }\end{array}$ & $\begin{array}{l}\text { In the four testing conditions, } \\
\text { two types of HPDs were used, an } \\
\text { electronic hearing protector and } \\
\text { conventional passive earmuff. } \\
\text { The electronic hearing protector } \\
\text { had three different settings (i.e., } \\
\text { off, low, and high). }\end{array}$ & $\begin{array}{l}\text { Repeated } \\
\text { measures }\end{array}$ & $\begin{array}{l}\text { Speech in- } \\
\text { telligibility }\end{array}$ & $\begin{array}{l}\text { Correct } \\
\text { percentage of } \\
\text { HINT test } \\
\text { score }(\%)\end{array}$ & $\begin{array}{l}\text { The results of } \\
\text { repeated-measures } \\
\text { ANOVA showed a } \\
\text { significant main effect } \\
{[\mathrm{F}(2,28)=1014.50,} \\
p<0.0001] \text { for the SNR } \\
\text { condition. The highest } \\
\text { scores were obtained } \\
\text { under the }+5 \mathrm{~dB} \text { SNR } \\
\text { condition, while the } \\
\text { lowest scores were } \\
\text { obtained under the } \\
-5 \mathrm{~dB} \text { SNR condition. } \\
\text { A significant main } \\
\text { effect was also found } \\
\text { for the earmuff } \\
\text { condition } \\
{[\mathrm{F}(3,42)=57.19,} \\
p<0.0001] \text {, } \\
\text { Additionally, the } \\
\text { interaction effect was } \\
\text { significant } \\
{[\mathrm{F}(6,84)=6.94,} \\
p<0.0001] \text {. }\end{array}$ & $\begin{array}{l}\text { For the types of HPDs, } \\
\text { passive muff showed the } \\
\text { highest correctness } \\
\text { percentage for the all } \\
\text { SNR conditions. While } \\
\text { the off and low settings } \\
\text { of electronic hearing } \\
\text { protector showed similar } \\
\text { correctness percentages, } \\
\text { and the high setting of } \\
\text { hearing protector showed } \\
\text { the lowest correctness } \\
\text { percentage, regardless of } \\
\text { the SNRs. }\end{array}$ \\
\hline $\begin{array}{l}\text { Carmichel } \\
\text { et al. } \\
\text { (2007) } \\
{[9]}\end{array}$ & $\begin{array}{l}\text { Eight normal } \\
\text { hearing listeners } \\
\text { (aged } 20 \text { to } \\
40 \text { years) }\end{array}$ & $\begin{array}{l}\text { Four stimuli (i.e., two successive } \\
\text { transient clicks of a } \\
\text { semiautomatic handgun being } \\
\text { loaded, the double ring of a } \\
\text { telephone with a mechanical } \\
\text { ringer, and electronically } \\
\text { generated FM tone bursts at } 0.5 \\
\text { and } 4 \mathrm{kHz} \text { ) and four HPDs (i.e., } \\
\text { electronic earmuffs, dynamic } \\
\text { level compression protectors, } \\
\text { action ear sport, and } \\
\text { unoccluded) were used. }\end{array}$ & $\begin{array}{l}\text { Repeated } \\
\text { measures }\end{array}$ & $\begin{array}{l}\text { Sound lo- } \\
\text { calization }\end{array}$ & $\begin{array}{l}\text { Localization } \\
\text { performance } \\
(\%) \text { and } \\
\text { response } \\
\text { time (sec) }\end{array}$ & $\begin{array}{l}\text { Differences in } \\
\text { localization among the } \\
\text { conditions were } \\
\text { significant for the } \\
\text { firearm }[\mathrm{F}(3,21)=15.30 \text {, } \\
p<0.05], \text { telephone } \\
{[\mathrm{F}(3,21)=15.40,} \\
p<0.05], 4 \mathrm{kHz} \text { tone } \\
\text { burst }[\mathrm{F}(3,21)=1.13, \\
p<0.05] \text { stimuli, but } \\
\text { not for the } 0.5 \mathrm{kHz} \\
\text { tone burst } \\
{[\mathrm{F}(3,21)=1.13 \text {, }} \\
p=0.36] \text {. The mean } \\
\text { response time showed } \\
\text { that there were } \\
\text { differences in the } \\
\text { conditions for the } \\
\text { broadband stimuli } \\
\text { (firearm, }[\mathrm{F}(3,21)=6.15, \\
p<0.05], \text { telephone } \\
{[\mathrm{F}(3,21)=5.21,} \\
p<0.05] .\end{array}$ & $\begin{array}{l}\text { The mean correct } \\
\text { responses for localization } \\
\text { to broadband stimuli in } \\
\text { the unoccluded condition } \\
\text { were } 97.2 \% \text { (firearm) and } \\
98.6 \% \text { (telephone). Mean } \\
\text { scores for localization to } \\
\text { these stimuli ranged from } \\
67.4 \text { to } 54.2 \% \text { correctness } \\
\text { in the HPD conditions } \\
\text { when averaged across all } \\
\text { locations. When } \\
\text { averaged across all } \\
\text { stimuli and locations, the } \\
\text { mean response time for } \\
\text { correct responses in the } \\
\text { unoccluded condition } \\
\text { (mean: } 1.58 \text { s, SD: } 0.76 \text { ) } \\
\text { was not different from } \\
\text { the mean response time } \\
\text { to errors (mean: } 1.64 \mathrm{~s}, \text { SD: } \\
0.81 \text { ). In the HPD } \\
\text { conditions, the mean } \\
\text { response time to incorrect } \\
\text { response was less (mean: } \\
1.88 \text { s, SD: } 0.89 \text { ) than to } \\
\text { correct responses (mean: } \\
1.90 \text { s, SD: } 0.81 \text { ) but these } \\
\text { differences were not } \\
\text { significant. }\end{array}$ \\
\hline
\end{tabular}


Table 3. Cont.

\begin{tabular}{|c|c|c|c|c|c|c|}
\hline Study & Participants & Test Materials and Conditions & $\begin{array}{c}\text { Study } \\
\text { Design }\end{array}$ & $\begin{array}{l}\text { Major } \\
\text { Function }\end{array}$ & $\begin{array}{l}\text { Outcome } \\
\text { Measures }\end{array}$ & Main Findings \\
\hline
\end{tabular}

Dastpaak Thirty-two adults Three ear conditions

(mean age:

et al.

[12] (unoccluded, HPD with 25 NRR

and HPD with 32 NRR) an

three SNR condition $(-10,0$, and

$+10 \mathrm{~dB}$ ) were used.
Repeated normal hearing telligibility
Averaged intelligibilit score $(\%)$
The results showed maximum speech intelligibility without HPDs and without noise and minimum average of speech intelligibility when the background noise was greater than the greater than the
$-10 \mathrm{~dB}$ SNR.
Given 100 dBA noise, earplugs showed significantly lower masked thresholds (91.9 dBA) than either the ANR muff (93.8 dBA) or the passive earmuff (95.5 dBA). Additionally, the ANR muff produced significantly lower masked thresholds than the passive muff did.

For the comparisons of types of HPDs, 32 of NRR HPD showed lower averaged intelligibility scores in all testing SNR conditions. While the without HPD condition showed $8.13 \%$ (SD: 9.11), $35.44 \%$ (SD: 19.11 ), and $35.44 \%$ (SD: 19.11 ), and three SNR conditions, three SNR conditions, showed $11.38 \%$ (SD: showed 11.38\% (SD: 9.64), $43.25 \%$ (SD: 17.54), and $78.06 \%$ (SD: 9.57 ). showed highest average intelligibility score for $-10 \mathrm{~dB}$ SNR (mean: $22.75 \%$, SD: 12.04), $0 \mathrm{~dB}$ SNR (mean: $55.31 \%$, SD: 14.41), and $-10 \mathrm{~dB}$ SNR (mean: $78.38 \%$, SD: 13.39).

The observed noise The mean noise attenuation for 60 ears de Faria Thirty adults with

(2008) (age range-20 to [22] 58 years)
Two HPDs with 21 and $17 \mathrm{~dB}$ measure attenuation.
Repeated measures

Noise Noise (decibels) lower than the

manufacturer's rating.

No ear achieved the uation, except at $500 \mathrm{~Hz}(35 \mathrm{~dB}$ NA). attenuation

measurements at each frequency were: (1) $500 \mathrm{~Hz}$ (mean: $22.8 \mathrm{~dB}$ D: 3.8), (2) $1000 \mathrm{~Hz}$ (mean: $23.4 \mathrm{~dB}, \mathrm{SD}: 3.7$ ), (3) $2000 \mathrm{HZ}$ (mean: $27.3 \mathrm{~dB}$, SD: 4.5$)$, and (4) ( $27.4 \mathrm{~dB}$, SD: 4.3

The passive HPD showed a mean decrease in of $27-29 \%$ across the noises compared to the unoccluded condition. However, when the level-dependent function was activated, it yielded average overall benefits of $11-15 \%$ and $23-24 \%$ of $11-15 \%$ and $23-24 \%$ respectively. The active HPD showed a mean HPD showed a mea ecrement in

of $17-25 \%$ compared to unprotected listening across the two noises. Unlikely for the passive HPD, an active HPD with activation of level-dependent function showed only a small effect on performance and a mean benefit of and a m. 
Table 3. Cont.

\begin{tabular}{|c|c|c|c|c|c|c|c|}
\hline Study & Participants & Test Materials and Conditions & $\begin{array}{c}\text { Study } \\
\text { Design }\end{array}$ & $\begin{array}{l}\text { Major } \\
\text { Function }\end{array}$ & $\begin{array}{l}\text { Outcome } \\
\text { Measures }\end{array}$ & Main Findings & Effects of HPD \\
\hline $\begin{array}{l}\text { Manning } \\
\text { et al. } \\
\text { (2016) } \\
{[27]}\end{array}$ & $\begin{array}{l}\text { A total of } 47 \\
\text { adults (19 with } \\
\text { normal hearing, } \\
15 \text { with SNHL, } \\
\text { and } 13 \text { with } \\
\text { SNHL and } \\
\text { tinnitus). }\end{array}$ & $\begin{array}{l}\text { A total of } 300 \text { items consisting of } \\
\text { six lists were used. The } \\
\text { background noise was presented } \\
\text { in three different SNR conditions } \\
\text { (i.e., quiet, }-6 \text { and }-12 \mathrm{~dB} \text { ). Two } \\
\text { types of TCAPS (i.e., in-ear } \\
\text { headset for air-conduction, and } \\
\text { headset for bone-conduction) } \\
\text { and two types of talker (male } \\
\text { and female) were used. }\end{array}$ & $\begin{array}{l}\text { Repeated } \\
\text { measures }\end{array}$ & $\begin{array}{l}\text { Speech in- } \\
\text { telligibility }\end{array}$ & $\begin{array}{l}\text { Mean } \\
\text { rationalized } \\
\text { arcsine units } \\
\text { (corrected) }\end{array}$ & $\begin{array}{l}\text { The mean rationalized } \\
\text { arcsine units measured } \\
\text { for each of the TCAPS } \\
\text { under test were } \\
\text { marginally, but } \\
\text { significantly better for } \\
\text { the bone-conduction } \\
\text { headset } \\
{[\mathrm{F}(1,528)=29.90,} \\
p<0.01] . \text { For the types } \\
\text { of hearing loss, the } \\
\text { effects of hearing loss } \\
\text { were found to be } \\
\text { statistically significant } \\
\text { [F(2,528) = 3.74, } \\
p<0.024] \text {. There was } \\
\text { no significant } \\
\text { interaction of hearing } \\
\text { loss with TCAPS } \\
{[\mathrm{F}(2,528)=0.99,} \\
p=0.372] \text {. In the SNR } \\
\text { conditions, } \\
\text { performance increased, } \\
\text { as the SNR increased } \\
{[\mathrm{F}(2,528)=1881.47,} \\
p<0.01] \text {. }\end{array}$ & $\begin{array}{l}\text { The normal hearing } \\
\text { listeners performed best, } \\
\text { and SNHL listeners } \\
\text { performed worst. The } \\
\text { degrading effect of noise } \\
\text { on speech recognition } \\
\text { was approximately the } \\
\text { same for the normal } \\
\text { hearing and hearing } \\
\text { impaired listeners; there } \\
\text { was no measurable } \\
\text { benefit for either TCAPS } \\
\text { in noise. }\end{array}$ \\
\hline $\begin{array}{l}\text { Plyler } \\
\text { and } \\
\text { Klump } \\
\text { (2003) } \\
{[19]}\end{array}$ & $\begin{array}{l}\text { Fourteen females } \\
\text { (age } 21 \text { to } \\
24 \text { years) with } \\
\text { normal hearing }\end{array}$ & $\begin{array}{l}\text { A total of three ear conditions } \\
\text { including unoccluded were used. } \\
\text { In the HPDs, no HPDs which } \\
\text { was custom acoustic HPD and } \\
\text { custom electronic HPD were } \\
\text { used. For the speech perception } \\
\text { test, two levels of noise ( } 75 \text { and } \\
90 \text { dB SPL) were used. The HINT } \\
\text { sentence lists were used as the } \\
\text { stimuli. }\end{array}$ & $\begin{array}{l}\text { Repeated } \\
\text { measures }\end{array}$ & $\begin{array}{l}\text { Speech in- } \\
\text { telligibility }\end{array}$ & $\begin{array}{l}\text { Relative } \\
\text { HINT score }\end{array}$ & $\begin{array}{l}\text { The analysis revealed a } \\
\text { significant main effect } \\
\text { for HPD }[\mathrm{F}(1,13)=10, \\
p<0.05] \text {. However, } \\
\text { main effects for } \\
\text { sentence presentation } \\
\text { level }[\mathrm{F}(1,13)=1 \text {, } \\
p>0.05] \text { were } \\
\text { significant. The } \\
\text { interaction between } \\
\text { sentence presentation } \\
\text { level } x \text { HPD } \\
{[\mathrm{F}(1,13)=2, p>0.05]} \\
\text { was not significant. } \\
\text { These results indicated } \\
\text { that communication } \\
\text { during noise was } \\
\text { significantly better } \\
\text { when utilizing the } \\
\text { acoustic HPD than } \\
\text { when utilizing the } \\
\text { electronic HPD at each } \\
\text { sentence presentation } \\
\text { level. }\end{array}$ & $\begin{array}{l}\text { The averaged relative } \\
\text { HINT scores indicated } \\
\text { that the acoustic HPD } \\
\text { showed } 1.1 \text { (SD: } 1.9 \text { ) } \\
\text { relative HINT score } \\
\text { which was higher than } \\
\text { the electronic HPD } \\
\text { (mean: - } 0.4, \text { SD: } 1.2 \text { ) at } \\
75 \mathrm{~dB} \text { SPL. In the } 90 \mathrm{~dB} \\
\text { SPL condition, acoustic } \\
\text { HPD (mean: } 0.1 \text {, SD: } 1.1 \text { ) } \\
\text { also showed higher } \\
\text { relative HINT score than } \\
\text { that for the electronic } \\
\text { HPD (mean: -0.6, SD: } \\
\text { 1.3). }\end{array}$ \\
\hline $\begin{array}{l}\text { Simpson } \\
\text { et al. } \\
\text { (2005) } \\
{[24]}\end{array}$ & $\begin{array}{l}\text { Seven adults (age } \\
18 \text { to } 39 \text { years) } \\
\text { with normal } \\
\text { hearing }\end{array}$ & $\begin{array}{l}\text { Four ear conditions (i.e., no HPD } \\
\text { (unoccluded), foam earplugs, } \\
\text { earmuffs, combination of } \\
\text { earplugs and earmuffs) and five } \\
\text { auditory cue conditions (four } \\
\text { HPDs condition and no cue } \\
\text { condition) were used. Stimuli } \\
\text { were visual targets with } \\
\text { continuous broadband ( } 70 \mathrm{~Hz} \text { to } \\
16 \mathrm{kHz} \text { ) pink noise. }\end{array}$ & $\begin{array}{l}\text { Repeated } \\
\text { measures }\end{array}$ & $\begin{array}{l}\text { Sound lo- } \\
\text { calization }\end{array}$ & $\begin{array}{l}\text { Response } \\
\text { accuracy (\%) } \\
\text { and search } \\
\text { time (sec) }\end{array}$ & $\begin{array}{l}\text { For response accuracy, } \\
\text { repeated-measures } \\
\text { ANOVA revealed that } \\
\text { neither of the main } \\
\text { effects nor the } \\
\text { interaction was found } \\
\text { to be statistically } \\
\text { significant }(p>0.05) \text {. } \\
\text { However, for search } \\
\text { time, repeated ANOVA } \\
\text { showed significant } \\
\text { main effects on the } \\
\text { auditory condition } \\
{[\mathrm{F}(4,24)=239.11 \text {, }} \\
p<0.05] \text { and set size } \\
{[\mathrm{F}(2,12)=328.75,} \\
p<0.05] . \text { The } \\
\text { interaction between } \\
\text { auditory condition and } \\
\text { set size }[\mathrm{F}(8,48)=93.84, \\
p<0.05] \text { was } \\
\text { significant. }\end{array}$ & $\begin{array}{l}\text { The unoccluded } \\
\text { condition had the lowest } \\
\text { search time, regardless of } \\
\text { the set size. Earmuff and } \\
\text { earplug conditions } \\
\text { showed similar search } \\
\text { times as a function of set } \\
\text { size. The combination of } \\
\text { earplugs and earmuffs } \\
\text { had a higher search time } \\
\text { than for other ear } \\
\text { conditions. }\end{array}$ \\
\hline
\end{tabular}


Table 3. Cont.

\begin{tabular}{|c|c|c|c|c|c|c|}
\hline Study & Participants & Test Materials and Conditions & $\begin{array}{c}\text { Study } \\
\text { Design }\end{array}$ & $\begin{array}{l}\text { Major } \\
\text { Function }\end{array}$ & $\begin{array}{l}\text { Outcome } \\
\text { Measures }\end{array}$ & Main Findings \\
\hline $\begin{array}{l}\text { Smalt } \\
\text { et al. } \\
\text { (2019) } \\
{[3]}\end{array}$ & $\begin{array}{l}\text { Thirteen adults } \\
\text { average age of } \\
31 \text { years with } \\
\text { normal hearing, } \\
\text { except for one } \\
\text { subject which } \\
\text { showed } 30 \mathrm{~dB} H \mathrm{HL} \\
\text { in one ear }\end{array}$ & $\begin{array}{l}\text { A total of four HPDs, two } \\
\text { passive types and two active } \\
\text { types, were used. For the speech } \\
\text { intelligibility test, Modified } \\
\text { Rhyme Test using three } \\
\text { background noises (i.e., } 60,75, \\
\text { and } 80 \text { dBA) was used. }\end{array}$ & $\begin{array}{l}\text { Repeated } \\
\text { measures }\end{array}$ & $\begin{array}{l}\text { Speech in- } \\
\text { telligibility }\end{array}$ & $\begin{array}{l}\text { Percentage } \\
\text { correct }(\%)\end{array}$ & $\begin{array}{l}\text { A two-way ANOVA } \\
\text { demonstrated that } \\
\text { there were significant } \\
\text { main effects for HPD } \\
{[\mathrm{F}(4,48)=3.716,} \\
p=0.010] \text { and noise } \\
\text { level }[\mathrm{F}(2,24)=1737, \\
p<2 \times 10^{-16} \text {. } \\
\text { However, the } \\
\text { interaction between } \\
\text { HPD and noise level } \\
\text { was not significant. For } \\
\text { the results of the post } \\
\text { hoc test, only the HPD } \\
\text { pair showed a } \\
\text { significant difference } \\
\text { between active HPDs } \\
(p=0.017) .\end{array}$ \\
\hline
\end{tabular}

Five ear conditions (i.e. unoccluded, earplug with $21 \mathrm{~dB}$ NRR and gain switch, ear tips $\begin{array}{ll}\text { Talcott } & \text { Thirteen adults } \\ \text { et al. } & \text { age } 22 \text { to } 54 \text { years }\end{array}$ (2012) with normal [10] hearing with $21 \mathrm{~dB}$ NRR, earplugs with $7 \mathrm{~dB}$ NRR, earmuff with $21 \mathrm{~dB}$ NRR) and two noise conditions (i.e., 45-50 dBA ambient noise and $82 \mathrm{dBA}$ diesel truck noise) were used.
Speech intelligibility was somewhat reduced for all the hearing protectors, but the differences induced by increasing the background noise level were much greater than the differences among the HPDs for a single noise level. $\begin{array}{ll}\begin{array}{l}\text { Repeated } \\ \text { measures }\end{array} & \begin{array}{l}\text { Sound lo- } \\ \text { calization }\end{array}\end{array}$ responst time $(\mathrm{sec})$
The ANOVA showed a significant main effect of the listening condition $(\mathrm{F}=17.22$, $p<0.0001)$. For the mean response time, the results of ANOVA a significant main effect of the listening condition $(\mathrm{F}=11.11$ condition (F
$p<0.0001)$. showed that there was

The percent of correct responses was

significantly lower for the earmuff $(21 \pm 10 \%)$ than all listening conditions and significantly greater for the unoccluded ear $55 \pm 17 \%$ ) than all stening conditions. No other differences were significant between the HPD conditions. In addition, the mean response time was significantly higher for the earmuff condition $(2.9 \pm 1.4 \mathrm{~s})$ than for all other HPDs and the unoccluded condition.

Mean per-frequency attenuation and mean PAR for each earplug type and training condition showed that the mean PAR of untrained non-custom plug produced $3.2 \mathrm{~dB}$ less attenuation than the attenuation than the
trained non-custom plug condition. For the custom plug, the untrained group showed $4.1 \mathrm{~dB}$ less mean PAR than the trained group. For the frequency comparison, the trained group showed higher attenuation values than the untrained group did for both custom and for both custom and
non-custom plugs.

$[\mathrm{F}(1,29)=0.29$ statistically significant.
In the SNR analysis, the main effects of

background noise $[\mathrm{F}(4,112)=3041.646$ $p<0.001]$
condition

$[\mathrm{F}(1,28)=4965.188$,

$[\mathrm{F}(1,28)=4965.188$ $p<0.001$ ] were

Two types of HPDs (i.e.,

Tufts Thirty-two adults and Frank (mean: 25.4 years (2003) SD: 4.9) with [13]

custom-molded foam ear plug and pre-molded earplug) were used. As stimuli, the 12 passages
from the 20 passages of the Speech Intelligibility Rating test
Repeated measures Speech intelligibility
Signal-tonoise ratio (dB) interactions of

background noise $\mathrm{x}$ ear condition $[\mathrm{F}(4,112)=60.568$ $p<0.001]$ and background noise $\mathrm{x}$ ear condition $x$ sex $p=0.034]$ were significant.

Two-way

repeated-measure ANOVA revealed the significant main effect of the test condition of the factor
$[\mathrm{F}(2.9,10.6)=68.33$, $[\mathrm{F}(2.9,10.6)$
$p<0.001]$
For background noise at $100 \mathrm{~dB}$ SPL, the overall speech levels were $84.4 \mathrm{~dB}$ for an and $71.9 \mathrm{~dB}$ and $74.3 \mathrm{~dB}$ for the custom-molded and pre-molded ear plugs. The corresponding SNRs were $-15.6,-28.1$ and $-25.7 \mathrm{~dB}$. unoccluded condition,

$\begin{array}{ll}\text { Zimpfer } & \text { Twenty listeners } \\ \text { and } & \text { (age 24-51 years) } \\ \text { Sarafian } & \text { with normal } \\ \text { (2014) } & \text { hearing } \\ \text { [25] } & \end{array}$

Five HPDs (four earplugs and one earmuff) were used where were active HPD.
Repeated

Sound lo-

Number of correct

and number of confusion
The unoccluded condition showed a significantly higher number of correct responses than any other HPDs conditions. Moreover, the active systems yielded lower scores (53 and $40 \%$ ) than did the passive systems (63\%). 


\subsection{Overall Functions and Effects of Hearing Protection Devices}

The results of effect size for the overall studies with the random effect model are presented in Figure 2A. Overall, the studies showed an SMD of 0.457 (95\% CI: 0.034-0.881, $p<0.05$ ), indicating that there was a significant functional difference. To identify the publication bias for the reviewed studies, a funnel plot is presented in Figure 2B. Not only was the funnel plot asymmetrical, but also the results of Egger's regression analysis showed that there was publication bias in the reviewed studies (intercept: 4.159, SE: 2.310, $p<0.05)$. Further, the results of Higgins $I^{2}$ statistics and Cochran's $Q$ test showed that heterogeneity was high $\left(I^{2}: 88.08\right.$, Q: $\left.159.369, p<0.001\right)$.

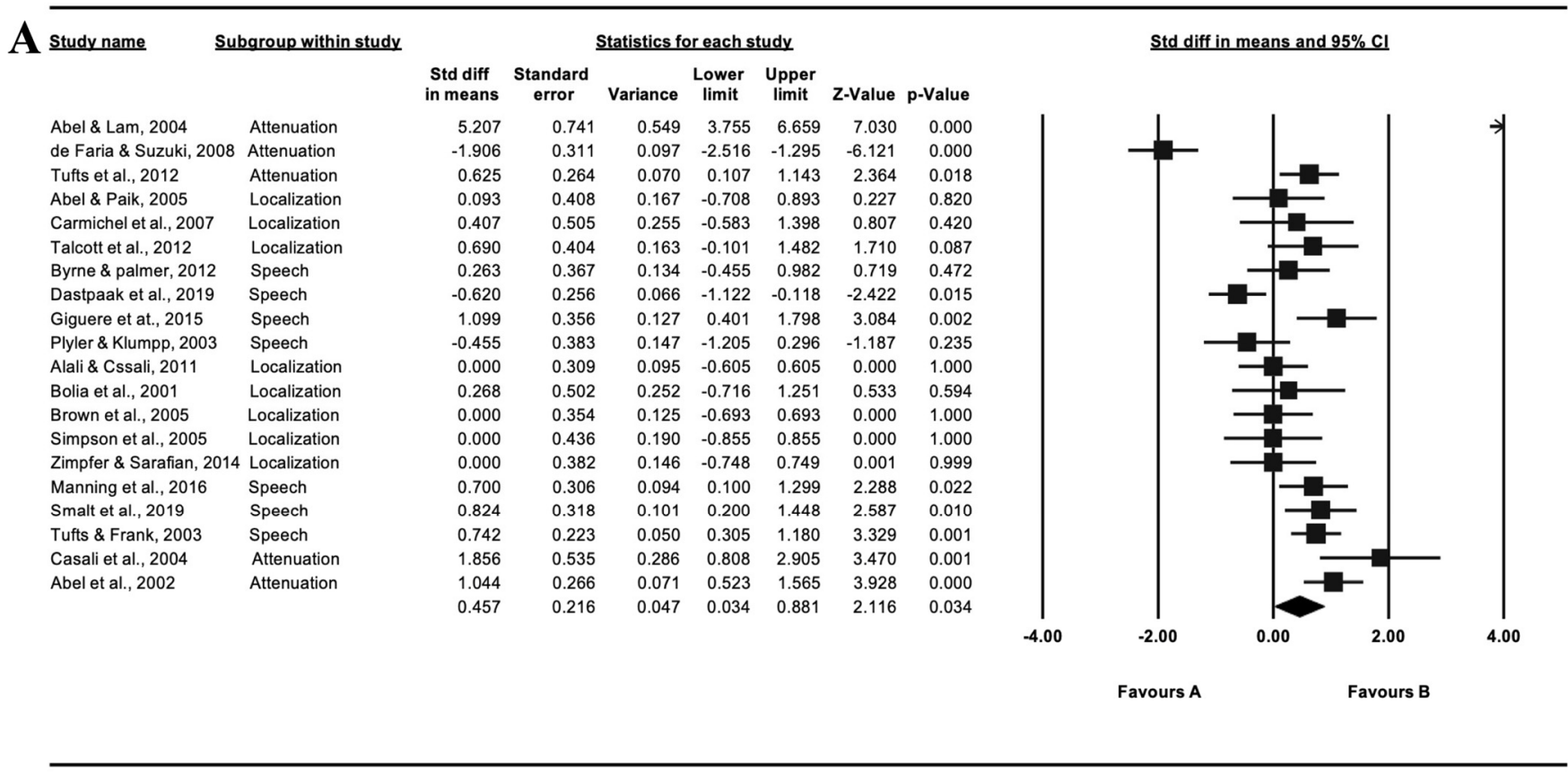

B

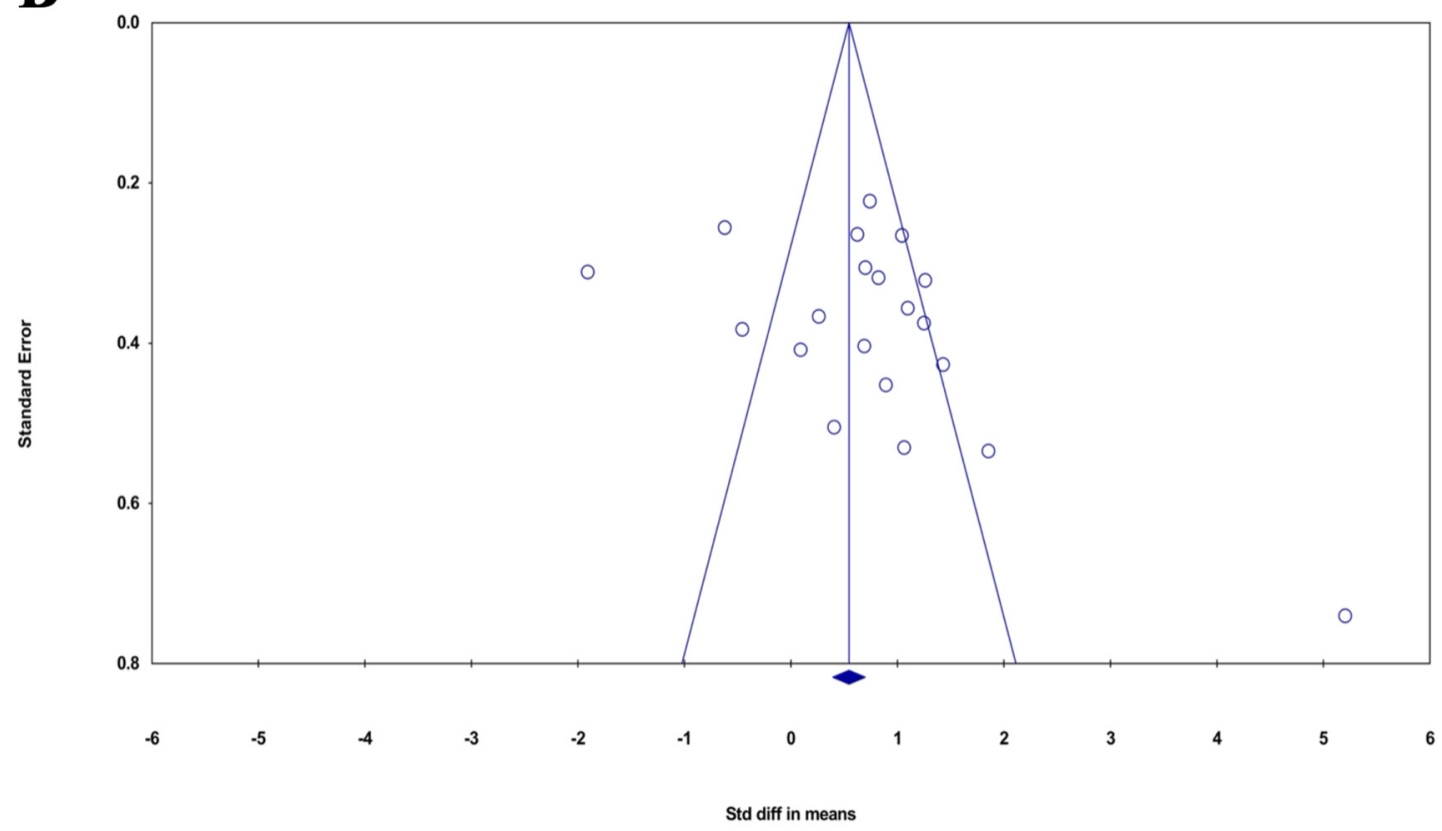

Figure 2. Forest plot of the twenty reviewed studies overall (A) and funnel plot of standard error for the standardized difference in means. Asymmetrical graph of funnel plot indicating publication bias (B). 


\subsection{Subgroup Analysis}

To identify the results of the meta-analysis more clearly, a subgroup analysis (i.e., attenuation, sound localization, and speech perception) was conducted. For the functions and effects of HPDs, a subgroup analysis was conducted and is presented in Figure 3. First, the effect size of sound attenuation which compared the hearing thresholds for the control (i.e., unoccluded and/or open ear) and an experimental group (i.e., wearing the HPDs) showed 1.080 (95\% CI: 0.167-1.993, $p<0.05$ ).

\begin{tabular}{|c|c|c|c|c|c|c|c|c|c|}
\hline \multirow{2}{*}{$\frac{\text { Group by }}{\text { Subgroup within study }}$} & \multirow[t]{2}{*}{ Study name } & \multirow[t]{2}{*}{$\underline{\text { Subgroup within study }}$} & \multicolumn{7}{|c|}{ Statistics for each study } \\
\hline & & & $\begin{array}{l}\text { Std diff } \\
\text { in means }\end{array}$ & $\begin{array}{l}\text { Standard } \\
\text { error }\end{array}$ & Variance & $\begin{array}{l}\text { Lower } \\
\text { limit }\end{array}$ & $\begin{array}{l}\text { Upper } \\
\text { limit }\end{array}$ & $z$-Value & $\mathrm{p}$-Value \\
\hline attenuation & Abel \& Lam, 2004 & attenuation & 5.207 & 0.741 & 0.549 & 3.755 & 6.659 & 7.030 & 0.000 \\
\hline attenuation & de Faria \& Suzuki, 2008 & attenuation & -1.906 & 0.311 & 0.097 & -2.516 & -1.295 & -6.121 & \\
\hline attenuation & Tufts et al., 2012 & attenuation & 0.625 & 0.264 & 0.070 & 0.107 & 1.143 & 2.364 & 0.018 \\
\hline attenuation & Casali et al., 2004 & attenuation & 1.856 & 0.535 & 0.286 & 0.808 & 2.905 & 3.470 & 0.001 \\
\hline attenuation & Abel et al., 2002 & attenuation & 1.044 & 0.266 & 0.071 & 0.523 & 1.565 & 3.928 & 0.000 \\
\hline attenuation & & & 1.080 & 0.466 & 0.217 & 0.167 & 1.993 & 2.318 & 0.020 \\
\hline localization & Abel \& Paik, 2005 & localization & 0.093 & 0.408 & 0.167 & -0.708 & 0.893 & 0.227 & 0.820 \\
\hline localization & Carmichel et al., 2007 & localization & 0.407 & 0.505 & 0.255 & -0.583 & 1.398 & 0.807 & \\
\hline localization & Talcott et al., 2012 & Iocalization & 0.690 & 0.404 & 0.163 & -0.101 & 1.482 & 1.710 & 0.087 \\
\hline localization & Alali \& Casali, 2011 & localization & 0.000 & 0.309 & 0.095 & -0.605 & 0.605 & 0.000 & 1.000 \\
\hline localization & Bolia et al., 2001 & localization & 0.268 & 0.502 & 0.252 & -0.716 & 1.251 & 0.533 & 0.594 \\
\hline localization & Brown et al., 2005 & localization & 0.000 & 0.354 & 0.125 & -0.693 & 0.693 & 0.000 & 1.000 \\
\hline localization & Simpson et al., 2005 & localization & 0.000 & 0.436 & 0.190 & -0.855 & 0.855 & 0.000 & \\
\hline localization & Zimpfer \& Sarafian, 2014 & 4 localization & 0.000 & 0.382 & 0.146 & -0.748 & 0.749 & 0.001 & 0.999 \\
\hline localization & & & 0.177 & 0.366 & 0.134 & -0.540 & 0.894 & 0.484 & \\
\hline Speech & Byme \& Palmer, 2012 & Speech & 0.263 & 0.367 & 0.134 & -0.455 & 0.982 & 0.719 & 0.472 \\
\hline Speech & Dastpaak et al., 2019 & Speech & -0.620 & 0.256 & 0.066 & -1.122 & -0.118 & -2.422 & \\
\hline Speech & Giguère et al., 2015 & Speech & 1.099 & 0.356 & 0.127 & 0.401 & 1.798 & 3.084 & 0.002 \\
\hline Speech & Plyler \& Klumpp, 2003 & Speech & -0.455 & 0.383 & 0.147 & -1.205 & 0.296 & -1.187 & \\
\hline Speech & Manning et al., 2016 & Speech & 0.700 & 0.306 & 0.094 & 0.100 & 1.299 & 2.288 & \\
\hline Speech & Smalt et al., 2019 & Speech & 0.824 & 0.318 & 0.101 & 0.200 & 1.448 & 2.587 & 0.01 \\
\hline Speech & Tufts \& Frank, 2003 & Speech & 0.742 & 0.223 & 0.050 & 0.305 & 1.180 & 3.329 & \\
\hline Speech & & & 0.366 & 0.378 & 0.143 & -0.375 & 1.106 & 0.968 & 0.33 \\
\hline Overall & & & 0.493 & 0.303 & 0.092 & -0.100 & 1.086 & 1.630 & \\
\hline
\end{tabular}

Figure 3. The forest plot of the subgroup analysis for sound attenuation $(n=6)$, sound localization $(n=9)$, and speech perception $(n=8)$.

Secondly, the subgroup analysis for sound localization included those studies that mainly reported the results for localization ability, such as the percentage correctness, response time, and azimuth error. These results confirmed that the ability of sound localization was not significantly different (SMD: $0.177,95 \%$ CI: $-0.540-0.894, p=0.628$ ) in individuals with HPDs compared to individuals without HPDs.

Finally, the studies that reported various speech perception performances (i.e., speech perception in noise, speech intelligibility, and word recognition ability) were classified as a subgroup of speech perception. The results for speech perception demonstrated that HPDs partially support the ability of speech perception, but they do not have any significant effect (SMD: 0.366, 95\% CI: $-0.375-1.106, p=0.333$ ).

\section{Discussion}

The primary purpose of the current study on systematic review and meta-analysis was to identify the effectiveness of HPDs. Three outcome measures, including sound attenuation, sound localization, and speech perception, were divided into two factors based on function (i.e., sound attenuation) and effect (i.e., sound localization and speech perception). Based on the effect size of a total of twenty reviewed studies, the functions and effects of HPDs that were revealed were significant. Several studies had a value 0 between the lower limit and upper limit of $95 \% \mathrm{CI}$ and/or a p-value higher than 0.05 which means there were high heterogeneities. These results might have occurred due to the small sample size. In fact, there were no studies that demonstrated a sample size calculation for their study design. 


\subsection{Do HPDs Effectively Attenuate the Level of Intensity of Unwanted Noise?}

The major and key functions of HPDs were revealed to be significantly effective, which means the hearing thresholds for the experimental group (wearing the HPDs) increased more than that of the control group (not wearing the HPDs). Abel and Lam reported that both conventional and level-dependent earplugs attenuated the input sounds from 21 to $40 \mathrm{~dB}$ and 5 to $22 \mathrm{~dB}$, respectively [20]. This result suggested that individuals who might recommend or willingly wear the HPDs have the choice to select HPDs to meet their purposes and situations. For example, the level-dependent earplugs were regarded as an alternative choice for the hearing-impaired or normal hearing in the case of a relatively not loud situation due to the increased hearing thresholds. According to Casali and colleagues [21], wearing HPDs significantly attenuated the sound more than not using HPDs. They also reported that masked thresholds when wearing HPDs at $85 \mathrm{dBA}$ were more significantly reduced than without having the HPDs condition. These results implied that HPDs could meet the role of their designated purpose.

Again, the HPDs are direct wearing devices, which were originally designated to prevent noise exposure and preserve hearing acuity [32]. Interestingly, Tufts et al. reported the effects of user training and fitting consistency [7]. Their results showed the significant effects of user training. Compared to non-customized earplugs, customized earplugs showed significantly better consistency of attenuation values at frequency ranges of 500, 1000, and $2000 \mathrm{~Hz}$. Moreover, the effects of user training were significant at three testing frequencies (i.e., 250, 500, and $1000 \mathrm{~Hz}$ ). These results suggest that the function of HPDs, especially for sound attenuation, could be improved and decrease the deviation for trials where individuals tried to wear HPDs. Regardless, to obtain the best benefit from the HPDs, an appropriate fitting method should be required [5] because the uncomfortable feeling of HPDs stems from an inadequate fitting method and/or the type of HPDs and is reported as a problem when wearing HPDs [4].

\subsection{Does Wearing HPDs Affect Sound Localization Ability for Their Users?}

The effects that occurred while wearing the HPDs were analyzed as sound localization ability. Sound localization was defined as a kind of ability, such as percentage correctness, response time, and azimuth error. The results of sound localization when wearing the HPDs could not significantly change the ability of sound localization compared to the condition of no HPDs $[4,8-10,24]$. In other words, wearing the HPDs did not interfere with sound localization, but it did not improve sound localization for their users. The reason why the HPDs failed to improve the ability of sound localization might be due to the distortions of high-frequency spectral cues [4]. Simpson et al. argued that double protection, such as a combination of earplugs with earmuffs, does not help localize the incoming sounds [24]. Simply, in terms of the latest technology of HPDs, active noise reduction HPDs may be better than the HPDs in terms of passive noise reduction. Still, Abel and Paik argued that not only the earmuff is not desirable to use for directionality, but also that the active noise reduction HPDs do not help recover the sound localization ability. In addition, the studies conducted by Carmichel et al. and Talcott et al. compared the two different functions of active and passive noise reduction HPDs and concluded that both noise reduction HPDs unfortunately did not recover the ability to determine sound localization $[9,10]$.

\subsection{Does Wearing an HPD Affect a User's Speech Perception Ability?}

In view of user ability to have speech perception, similar to sound localization ability, the effect of HPDs was not significant based on the current meta-analysis. Since many of the studies that have reported the function of HPDs for speech perception ability are controversial, we believe that a current decisive and unified analysis is more informative. That is, three of seven studies which were clustered as a subgroup of speech perception argued that to wear HPDs did not improve speech perception ability [3,11,13]. Smalt et al. further reported the effects of HPDs on the listening effort, which was regarded as cognitive 
resources for auditory tasks [3]. They concluded that the use of HPDs increased the amount of listening effort. This increased listening effort produced cognitive fatigue, especially in noisy circumstances.

On the other hand, three studies posited that wearing HPDs could improve speech perception performance $[12,26,27]$. Although passive noise reduction HPDs which have a low noise reduction rating (NRR) showed increased speech intelligibility in the presence of background noise [12], active noise reduction HPDs provided substantial benefits for speech recognition performance, especially for the hearing-impaired users [26]. Plyler and Klumpp also suggested that active noise reduction HPDs may be beneficial for individuals with sensorineural hearing loss [19]. Further considering the characteristics and requirements of users who would be recommended and/or mandated for HPDs, Manning et al. reported on the benefits of bone-conduction HPDs for tinnitus patients [27]. They conducted speech recognition tasks under noisy circumstances for tinnitus patients, the hearing-impaired users, and normal hearing listeners, using both air- and bone-conduction HPDs. The authors reported that bone-conduction HPDs exhibited better performances than air-conduction HPDs did in all groups.

\section{Conclusions}

Based on the present systematic review that included meta-analysis, the HPDs performed well for their originally designated function, i.e., sound attenuation, without interfering with finding a location from the sound sources and talk between the workers. It is obvious that HPDs provide great benefits in specific situations and/or for individuals, such as in the presence of high-intensity noise, military soldiers, and occupational workers, $\mathrm{b}$ due to the attenuation of HPDs. Furthermore, the performance of sound localization and speech perception were not negatively affected for those users wearing the HPDs.

Although the present systematic review and meta-analysis were conducted with specific purposes, such as the evaluation of major functions and effects (i.e., sound attenuation, sound localization, and speech perception) of HPDs, a comparison between passive and active HPDs was not considered. For example, six articles used passive HPDs, and fourteen articles used active HPDs in the twenty reviewed articles. It is obvious that the mechanisms of passive HPDs and active HPDs are differently enacted, and these types of mechanisms for HPDs should be discussed in further.

In conclusion, because the results of HPDs analysis from many previous studies are controversial, high-level evidence of using HPDs will need to include evidence-based guidelines for those individuals who are recommended and/or mandated to wear HPDs.

Author Contributions: Conceptualization: C.K. and W.H.; Formal analysis: C.K.; Funding acquisition: W.H.; Methodology: C.K. and W.H.; Supervision: W.H.; Validation: W.H.; Visualization: C.K.; Writing-original draft: C.K.; Writing—review and editing: W.H. All authors have read and agreed to the published version of the manuscript.

Funding: This work was supported by the Hallym University Research Fund (HRF-202109-006).

Institutional Review Board Statement: Not Applicable.

Informed Consent Statement: Not Applicable.

Data Availability Statement: The datasets used and/or analyzed for current study are available from the corresponding author on reasonable request.

Conflicts of Interest: The authors declare no conflict of interest.

\section{References}

1. Chung, I.S.; Chu, I.M.; Cullen, M.R. Hearing effects from intermittent and continuous noise exposure in a study of Korean factory workers and firefighters. BMC Public Health 2012, 12, 1-7. [CrossRef]

2. MacGregor, A.J.; Joseph, A.R.; Walker, G.J.; Dougherty, A.L. Co-occurrence of hearing loss and posttraumatic stress disorder among injured military personnel: A retrospective study. BMC Public Health 2020, 20, 1-7. [CrossRef] 
3. Smalt, C.J.; Calamia, P.T.; Dumas, A.P.; Perricone, J.P.; Patel, T.; Bobrow, J.; Collins, P.P.; Markey, M.L.; Quatieri, T.F. The Effect of Hearing-Protection Devices on Auditory Situational Awareness and Listening Effort. Ear Hear. 2020, 41, 82-94. [CrossRef]

4. Brown, A.D.; Beemer, B.T.; Greene, N.T.; Argo IV, T.; Meegan, G.D.; Tollin, D.J. Effects of active and passive hearing protection devices on sound source localization, speech recognition, and tone detection. PLoS ONE 2015, 10, e0136568. [CrossRef] [PubMed]

5. Abel, S.M.; Sass-Kortsak, A.; Kielar, A. The effect on earmuff attenuation of other safety gear worn in combination. Noise Health 2002, 5, 1-13.

6. Song, H.; Jeong, S.; Lee, E.; Alsabbagh, N.; Lee, J.; You, S.; Kwak, C.; Kim, S.; Han, W. Types of hearing protection devices and application. Korean J. Otorhinolaryngol.-Head Neck Surg. 2019, 62, 1-14. [CrossRef]

7. Tufts, J.B.; Jahn, K.N.; Byram, J.P. Consistency of attenuation across multiple fittings of custom and non-custom earplugs. Ann. Occup. Hyg. 2013, 57, 571-580.

8. Abel, S.M.; Paik, J.S. Sound source identification with ANR earmuffs. Noise Health 2005, 7, 1-10. [CrossRef] [PubMed]

9. Carmichel, E.L.; Harris, F.P.; Story, B.H. Effects of binaural electronic hearing protectors on localization and response time to sounds in the horizontal plane. Noise Health 2007, 9, 83-95.

10. Talcott, K.A.; Casali, J.G.; Keady, J.P.; Killion, M.C. Azimuthal auditory localization of gunshots in a realistic field environment: Effects of open-ear versus hearing protection-enhancement devices (HPEDs), military vehicle noise, and hearing impairment. Int. J. Audiol. 2012, 51, S20-S30. [CrossRef] [PubMed]

11. Byrne, D.C.; Palmer, C.V. Comparison of speech intelligibility measures for an electronic amplifying earmuff and an identical passive attenuation device. Audiol. Res. 2012, 2, 17-24. [CrossRef]

12. Dastpaak, H.; Alimohammadi, I.; jalal Sameni, S.; Abolghasemi, J.; Vosoughi, S. Effects of earplug hearing protectors on the intelligibility of Persian words in noisy environments. Appl. Acoust. 2019, 148, 19-22. [CrossRef]

13. Tufts, J.B.; Frank, T. Speech production in noise with and without hearing protection. J. Acoust. Soc. Am. 2003, 114, 1069-1080. [CrossRef] [PubMed]

14. Page, M.J.; McKenzie, J.E.; Bossuyt, P.M.; Boutron, I.; Hoffmann, T.C.; Mulrow, C.D.; Shamseer, L.; Tetzlaff, J.M.; Akl, E.A.; Brennan, S.E.; et al. The PRISMA 2020 statement: An updated guideline for reporting systematic revies. BMJ 2021, 372, 1-9.

15. PROSPERO, Centre for Reviews and Dissemination. Title of subordinate document. International Prospective Register of Systematic Reviews. Centre for Reviews and Dissemination. 2014. Available online: http://cdn.elsevier.com/promis_misc/ PROSPEROAnimal.pdf (accessed on 5 April 2021).

16. Macleod, M.R.; O'Collins, T.; Horky, L.L.; Howells, D.W.; Donnan, G.A. Systematic review and metaanalysis of the efficacy of FK506 in experimental stroke. J. Cereb. Blood Flow Metab. 2005, 25, 713-721. [CrossRef] [PubMed]

17. Group, G.W. Grading quality of evidence and strength of recommendations. BMJ 2004, 328, 1490-1494.

18. Alali, K.A.; Casali, J.G. The challenge of localizing vehicle backup alarms: Effects of passive and electronic hearing protectors, ambient noise level, and backup alarm spectral content. Noise Health 2011, 13, 99-112. [PubMed]

19. Plyler, P.N.; Klumpp, M.L. Communication in noise with acoustic and electronic hearing protection devices. J. Am. Acad. Audiol. 2003, 14, 260-268. [CrossRef]

20. Abel, S.M.; Lam, Q. Sound attenuation of the indoor/outdoor range EAR plug. Mil. Med. 2004, 169, 551-555. [CrossRef] [PubMed]

21. Casali, J.G.; Robinson, G.S.; Dabney, E.C.; Gauger, D. Effect of electronic ANR and conventional hearing protectors on vehicle backup alarm detection in noise. Hum. Factors 2004, 46, 1-10. [CrossRef]

22. de Faria, C.A.R.; Suzuki, F.A. Pure tone audiometry with and without specific ear protectors. Braz. J. Otorhinolaryngol. 2008, 74, 417-422. [CrossRef]

23. Bolia, R.S.; D'Angelo, W.R.; Mishler, P.J.; Morris, L.J. Effects of hearing protectors on auditory localization in azimuth and elevation. Hum. Factors 2001, 43, 122-128. [CrossRef] [PubMed]

24. Simpson, B.D.; Bolia, R.S.; McKinley, R.L.; Brungart, D.S. The impact of hearing protection on sound localization and orienting behavior. Hum. Factors 2005, 47, 188-198. [CrossRef] [PubMed]

25. Zimpfer, V.; Sarafian, D. Impact of hearing protection devices on sound localization performance. Front. Neurosci. 2014, 8, 1-10. [CrossRef]

26. Giguère, C.; Laroche, C.; Vaillancourt, V. The interaction of hearing loss and level-dependent hearing protection on speech recognition in noise. Int. J. Audiol. 2015, 54, S9-S18. [CrossRef] [PubMed]

27. Manning, C.; Mermagen, T.; Scharine, A. The effect of sensorineural hearing loss and tinnitus on speech recognition over air and bone conduction military communications headsets. Hear. Res. 2017, 349, 67-75. [CrossRef]

28. Higgins, J.P.; Thompson, S.G.; Deeks, J.J.; Altman, D.G. Measuring inconsistency in meta-analysis. BMJ 2003, 327, 557-560. [CrossRef] [PubMed]

29. Simes, R.J. Confronting publication bias: A cohort design for meta-analysis. Stat. Med. 1987, 6, 11-29. [CrossRef]

30. The R Foundation. R: A Language and Environment for Statistical Computing. The R Foundation. 2018. Available online: https://www.R-project.org/ (accessed on 7 April 2021).

31. Henshaw, H.; Ferguson, M.A. Efficacy of individual computer-based auditory training for people with hearing loss: A systematic review of the evidence. PLoS ONE 2013, 8, e62836. [CrossRef]

32. Rawool, V.W. Conservation and management of hearing loss in musicians. In Hearing Conservation in Occupational, Recreational, Educational, and Home Settings, 1st ed.; Rawool, V.W., Ed.; Thieme: New York, NY, USA, 2012; pp. 201-223. 